\title{
molecules
}

ISSN 1420-3049

www.mdpi.com/journal/molecules

Article

\section{3-H-[1,2]Dithiole as a New Anti-Trypanosoma cruzi Chemotype: Biological and Mechanism of Action Studies}

\author{
Marcos Couto ${ }^{1}$, Carina Sánchez ${ }^{1}$, Belén Dávila ${ }^{1}$, Valentina Machín ${ }^{1}$, Javier Varela ${ }^{1}$, \\ Guzmán Álvarez ${ }^{1, \dagger}$, Mauricio Cabrera ${ }^{1, \dagger}$, Laura Celano ${ }^{2}$, Beatriz Aguirre-López ${ }^{3}$, \\ Nallely Cabrera ${ }^{3}$, Marieta Tuena de Gómez-Puyou ${ }^{3}$, Armando Gómez-Puyou ${ }^{3}$, \\ Ruy Pérez-Montfort ${ }^{3}$, Hugo Cerecetto ${ }^{1, \hbar, *}$ and Mercedes González ${ }^{1, *}$
}

1 Grupo de Química Medicinal-Laboratorio de Química Orgánica, Facultad de Ciencias, Universidad de la República, Iguá 4225, Montevideo C.P. 11400, Uruguay; E-Mails: mcoutosire@gmail.com (M.C.); caarisanchez@hotmail.com (C.S.); BelenDav@gmail.com (B.D.); valeentiina.m@gmail.com (V.M.); jvarelaubillos@gmail.com (J.V.); guzmanalvarezlqo@gmail.com (G.Á.); mauriciocabreracedres@gmail.com (M.C.)

2 Laboratorio de Enzimología, Facultad de Ciencias, Universidad de la República, Iguá 4225, Montevideo C.P. 11400, Uruguay; E-Mail: 1celano@fcien.edu.uy

3 Departamento de Bioquímica y Biología Estructural, Instituto de Fisiología Celular, Universidad Nacional Autónoma de México, Ciudad de México 04510, Mexico; E-Mails: bety.aguirre.lopez@gmail.com (B.A.-L.); ncabrera@ifc.unam.mx (N.C.); mtuena@ifc.unam.mx (M.T.G.-P.); apuyou@ifc.unam.mx (A.G.-P.); ruy@ifc.unam.mx (R.P.-M.)

† Current address: Laboratorio de Moléculas Bioactivas, CENUR Litoral Norte, Universidad de la República, Ruta 3 (km 363), Paysandú C.P. 60000, Uruguay.

* Current address: Área de Radiofarmacia, Centro de Investigaciones Nucleares, Universidad de la República, Mataojo 2055, Montevideo C.P. 11400, Uruguay.

* Authors to whom correspondence should be addressed; E-Mails: hcerecetto@gmail.com or hcerecetto@cin.edu.uy (H.C.); megonzal@fq.edu.uy or mgonzalezhormaizteguy@gmail.com (M.G.); Tel.: +598-2525-8618 (H.C. \& M.G.); Fax: +598-2525-0749 (H.C. \& M.G.).

Academic Editor: Christophe Dardonville

Received: 29 May 2015 / Accepted: 7 August 2015 / Published: 12 August 2015

Abstract: The current pharmacological Chagas disease treatments, using Nifurtimox or Benznidazole, show limited therapeutic results and are associated with potential side effects, 
like mutagenicity. Using random screening we have identified new chemotypes that were able to inhibit relevant targets of the Trypanosoma cruzi. We found $3 H$-[1,2]dithioles with the ability to inhibit Trypanosoma cruzi triosephosphate isomerase (TcTIM). Herein, we studied the structural modifications of this chemotype to analyze the influence of volume, lipophilicity and electronic properties in the anti-T. cruzi activity. Their selectivity to parasites vs. mammalian cells was also examined. To get insights into a possible mechanism of action, the inhibition of the enzymatic activity of TcTIM and cruzipain, using the isolated enzymes, and the inhibition of membrane sterol biosynthesis and excreted metabolites, using the whole parasite, were achieved. We found that this structural framework is interesting for the generation of innovative drugs for the treatment of Chagas disease.

Keywords: anti-T. cruzi activity; 3H-1,2-dithiole; triosephosphate isomerase; cruzipain; membrane sterol biosynthesis; ${ }^{1} \mathrm{H}-\mathrm{NMR}$ metabolomics

\section{Introduction}

American trypanosomiasis, Chagas disease, is transmitted to humans by bites and concomitant defecation of different triatomine species, which carry the flagellate parasite Trypanosoma cruzi (T. cruzi) in their contaminated feces. It is an endemic disease that affects nearly 10 million people, generating health, economic and social problems in the affected countries [1]. Although the disease is native to Central and South America, nowadays both the population mobility between Latin America and the rest of the world, or the residence in endemic areas, have made it a worldwide problem.

Like other neglected diseases, it is a major health problem resulting from inadequate therapy and the lack of an effective vaccine [2,3]. Treatment of Chagas disease requires long-term dosage regimes with nifurtimox (Nfx; Lampit, Bayer Healthcare, Leverkusen) or benznidazole (Bnz; LAFEPE, Pernambuco), however, severe side effects often prompt the discontinuation of the treatment [4]. Among other relevant problems, these drugs exhibit significant mutagenic effects, and in some studies have been shown to be tumorigenic or carcinogenic [5].

As part of our ongoing program in search of small molecular weight compounds that could provide leads in the design of new drugs for the treatment of Chagas disease [6], we undertook a massive screening for inhibitors of Trypanosoma cruzi triosephosphate isomerase (TcTIM). TcTIM is considered a potential target for anti-trypanosomal drugs [7-9]. This enzyme is involved in the glycolysis pathway of the parasite. We evaluated nearly 300 compounds from our in-house library against TcTIM, identifying good inhibitors [10-13] and also hits with the ability to act as potential inhibitors, after further structural modifications. Of these hits we identified two compounds with an original framework in the context of anti-trypanosomal agents, the $3 H$-[1,2]dithiole heterocycles. These are compounds 1 and 2 (Figure 1A) [14], which, at $25 \mu \mathrm{M}$, had high percentages of TcTIM inhibition, 33\% and 48\%, respectively. These compounds are structurally related to one of our best TcTIM inhibitors, the [1,2,4]thiadiazol-5(4H)-one 3 (Figure 1B) [11]. 
(A)

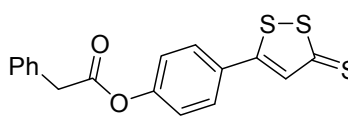

(1)

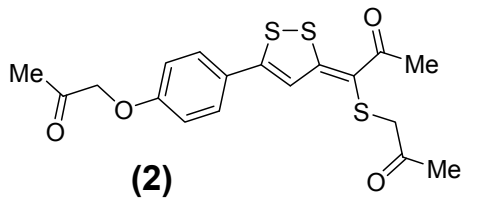

(2)

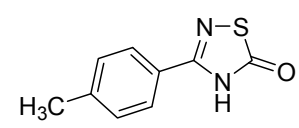

(3)

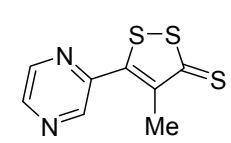

(4)

Figure 1. (A) Structures of the new hits, belonging to $3 H$-[1,2]dithiole chemotype and identified as TcTIM inhibitors; (B) Structure of our best TcTIM inhibitor described to date [11]; (C) Structure of oltipraz.

On the other hand, the 3-H-1,2-dithiole heterocycle has been previously described as the framework responsible for schistosomicidal activity, e.g., in oltipraz (4, Figure 1C) [15].

However, according to our knowledge, there are no descriptions about the use of this kind of heterocycle as a drug pharmacophore for Chagas disease.

The present study was undertaken in order to investigate the potential of different $3 H$-[1,2]dithiole derivatives as anti-T. cruzi agents and also to attempt to elucidate their mechanism(s) of action.

\section{Results and Discussion}

\subsection{Synthesis of 3-H-[1,2]Dithiole Derivatives}

For the synthesis of the 3H-[1,2]dithiole derivatives 1, 2 and 5-21 (Figure 2), we used anethole as starting material [16]. From the dithiolethione $\mathbf{6}$ we prepared esters 1, and 7-9 via coupling with DCC/DMAP [14]. The (E)-3-[1-(alkylthio)propylidene]-3H-[1,2]dithioles 2, and 13-17 were obtained using different $\alpha$-haloketones in the presence of excess potassium iodide, according to previously reported protocols, starting from dithiolethiones 5 or $\mathbf{6}$ [17]. Additionally, in these reactions, products $\mathbf{1 0}-\mathbf{1 2}$ and iodide salts 18-21 were also isolated. All the new compounds, 12, 14, 17, 18, and 21, were characterized by ${ }^{1} \mathrm{H}-\mathrm{NMR},{ }^{13} \mathrm{C}-\mathrm{NMR}$, COSY, HSQC, and HMBC experiments, and MS. According to $\mathrm{H}-\mathrm{H}$ coupling constants and NOE-diff experiments, the compounds were obtained as the $E$-isomer around the alkenic moiety. The purity of the synthesized compounds was established by TLC and elemental analysis $(C, H, N)$. Only compounds with analytical results within \pm 0.4 of the theoretical values were considered pure enough for biological testing. 


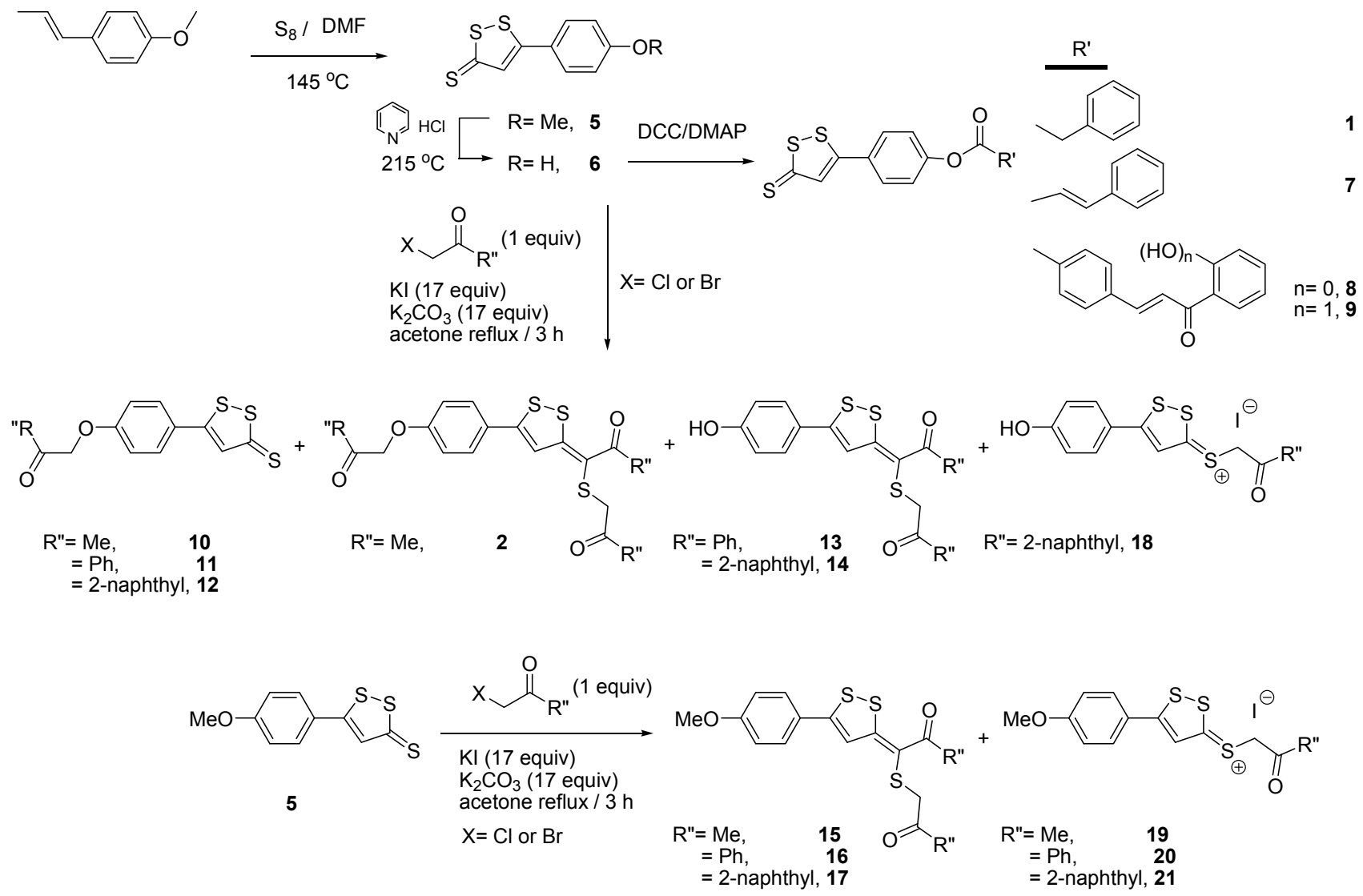

Figure 2. Synthetic procedures used to prepare the dithiole derivatives.

\subsection{In Vitro Biological Studies}

To evaluate the anti-trypanosomal activity of the synthesized $3 H$-[1,2]dithioles we used T. cruzi, Tulahuen 2 strain (discrete typing unit, DTU, TcVI [18]) in the epimastigote form. Initially working at $25 \mu \mathrm{M}$, the IC50 was determined for compounds showing $70 \%$ of growth inhibition at this concentration (Table 1) [19]. To establish the selectivity of the compounds against the parasite, unspecific cytotoxicity against mammalian cells (J774.1 murine macrophages) was studied for the most relevant derivatives. The selectivity indexes (SI) were also determined (Table 1).

In general, the 3H-[1,2]dithiole-3-thiones had modest activity against T. cruzi, with phenols 6 and 9 showing the lowest $\mathrm{IC}_{50}$. Additionally, they had some level of parasite selectivity, SI $\sim 2.0$ (Table 1).

The iodide salts 18-21 were also inactive against $T$. cruzi (Table 1) probably as result of their higher hydrophilicities and a lower ability to cross the cellular membrane.

On the contrary, the 3-propylidene-3H-[1,2]dithioles displayed noteworthy activity against the epimastigotes of $T$. cruzi, being equipotent to the reference trypanosomicidal drugs $\mathrm{Nfx}$ and Bnz $\left(\mathrm{IC}_{50, \mathrm{Nfx}}=8.0 \pm 1.0 \mu \mathrm{M}, \mathrm{IC}_{50, \mathrm{Bnz}}=7.0 \pm 1.0 \mu \mathrm{M}[19]\right)$. Again, phenols 13 and $\mathbf{1 4}$ were the most potent derivatives and, additionally, they had the highest selectivity (SI $>6.0$ ). Consequently, the 3-(alkylthio)propylidene-3H-[1,2]dithiole structural framework emerges as a new hit for the development of anti-trypanosomal drugs. 
Table 1. Effects of the studied compounds against epimastigotes of T. cruzi (Tulahuen 2 strain) and murine macrophages (J774.1). The experiments were done in triplicate.

\begin{tabular}{|c|c|c|c|c|c|}
\hline Family & Derivative & $\begin{array}{c}\mathrm{IC}_{50} \text { against } \\
\text { T. cruzi }(\mu \mathrm{M})\end{array}$ & $\begin{array}{c}\mathrm{IC}_{50} \text { against } \\
\text { Macrophages }(\boldsymbol{\mu M})\end{array}$ & SI & $\operatorname{miLog} \mathrm{P}^{\mathrm{a}}$ \\
\hline \multirow{9}{*}{$3 H$-[1,2]dithiole-3-thiones } & 1 & $>25$ & $-b$ & - & 4.66 \\
\hline & 5 & $>25$ & - & - & 3.57 \\
\hline & 6 & $25.0 \pm 1.0$ & $51 \pm 2$ & 2.0 & 3.04 \\
\hline & 7 & $>25$ & - & - & 5.21 \\
\hline & 8 & $>25$ & - & - & 7.26 \\
\hline & 9 & $25.0 \pm 0.5$ & $63 \pm 2$ & 2.5 & 7.20 \\
\hline & 10 & $>25$ & - & - & 3.12 \\
\hline & 11 & $>25$ & - & - & 4.72 \\
\hline & 12 & $>25$ & - & - & 5.91 \\
\hline \multirow{6}{*}{$\begin{array}{c}\text { 3-(alkylthio)propylidene- } \\
3 H \text { - }[1,2] \text { dithioles }\end{array}$} & 2 & $7.7 \pm 1.4$ & $24 \pm 1$ & 3.1 & 3.16 \\
\hline & 13 & $5.5 \pm 0.9$ & $34.0 \pm 0.5$ & 6.2 & 6.28 \\
\hline & 14 & $4.9 \pm 1.1$ & $63 \pm 2$ & 12.8 & 8.50 \\
\hline & 15 & $5.9 \pm 1.2$ & $<24.0$ & $<4.1$ & 3.61 \\
\hline & 16 & $>25$ & - & - & 6.82 \\
\hline & 17 & $>25$ & - & - & 8.77 \\
\hline \multirow{4}{*}{ [1,2]dithiolium iodide } & 18 & $>25$ & - & & 3.25 \\
\hline & 19 & $>25$ & - & - & 4.07 \\
\hline & 20 & $>25$ & - & - & 2.60 \\
\hline & 21 & $>25$ & - & - & 3.78 \\
\hline
\end{tabular}

${ }^{a}$ LoP determined using Molinspiration online property calculation toolkit [20]. ${ }^{\mathrm{b}}$-: not determined.

The lipophilicity seems to be partially related with the anti-Trypanosoma cruzi activity. The three most hydrophilic compounds, $\mathbf{6 , 1 0}$ and 20, were inactive against the whole parasite. The same occurs with the most lipophilic compound, 17. Similarly with the unspecific toxicity, the most lipophilic compounds $\mathbf{9}$ and $\mathbf{1 4}$ were the least cytotoxic. This physicochemical property is not the only related to the activity because no statistically significant correlation could be established.

\subsection{Accessing the Mechanism of Action of the New Active Anti-T. cruzi Agents}

In order to identify the potential modes of action of these new anti-T. cruzi agents, we made different kinds of experiments. Firstly, the compounds were tested as inhibitors of two relevant and validated targets of T. cruzi: the glycolytic enzyme triosephosphate isomerase (TcTIM) and the protease cruzipain. Besides the studies on the isolated enzymes, we included two different types of experiments using the entire parasites. We studied the effects of the compounds on the pathways of membrane sterol biosynthesis. Also, we analyzed the modifications of the excreted metabolites.

\subsubsection{Inhibition of TcTIM}

In order to investigate if the $3 H$-[1,2]dithioles inhibit TcTIM, we initially tested the inhibitory capacity of the compounds at a concentration of $200 \mu \mathrm{M}$ and then at $25 \mu \mathrm{M}$. If the compound inhibited the enzymatic activity by more than $60 \%$ at $25 \mu \mathrm{M}$, the IC50 was determined (Table 2) [10-12]. 
Table 2. Inhibition of enzymatic activity of TcTIM and cruzipain. The experiments were done in triplicate.

\begin{tabular}{|c|c|c|c|c|c|c|}
\hline \multirow{2}{*}{ Family } & \multirow{2}{*}{ Derivative } & \multicolumn{3}{|c|}{ TcTIM } & \multicolumn{2}{|c|}{ Cruzipain } \\
\hline & & $\%$ Inhib $_{200}{ }^{a}$ & $\%$ Inhib $_{25}{ }^{a}$ & $\mathrm{IC}_{50}(\boldsymbol{\mu M})$ & $\%$ Inhib $_{100}{ }^{a}$ & $\mathrm{IC}_{50}(\mu \mathrm{M})$ \\
\hline \multirow{9}{*}{$3 H$-[1,2]dithiole-3-thiones } & 1 & 77 & $33 \pm 1.9$ & $-b$ & $21.3 \pm 0.3$ & - \\
\hline & 5 & 86 & $80 \pm 2.3$ & $1.2 \pm 0.05$ & $89.0 \pm 0.5$ & $4.0 \pm 2.0$ \\
\hline & 6 & 71 & $35 \pm 3.0$ & - & $59.3 \pm 0.3$ & - \\
\hline & 7 & 14 & - & - & $78.4 \pm 0.6$ & - \\
\hline & 8 & $\mathrm{~ns}^{\mathrm{c}}$ & - & - & $58.0 \pm 0.1$ & - \\
\hline & 9 & 50 & - & - & $77.9 \pm 0.6$ & - \\
\hline & 10 & 70 & $61 \pm 1.0$ & - & $73.9 \pm 0.1$ & - \\
\hline & 11 & ns & - & - & $96.3 \pm 0.7$ & $17.1 \pm 3.6$ \\
\hline & 12 & 70 & $\mathrm{ni}^{\mathrm{d}}$ & - & $91.5 \pm 0.6$ & $21.6 \pm 6.1$ \\
\hline \multirow{6}{*}{$\begin{array}{c}\text { 3-(alkylthio)propylidene- } \\
\text { 3H-[1,2]dithioles }\end{array}$} & 2 & 72 & $48 \pm 4.0$ & - & $91.3 \pm 2.8$ & $15.5 \pm 2.7$ \\
\hline & 13 & 86 & $75 \pm 6.0$ & $3.35 \pm 0.14$ & $61.0 \pm 0.3$ & - \\
\hline & 14 & 70 & $38 \pm 3.5$ & - & $66.5 \pm 0.3$ & - \\
\hline & 15 & 86 & $62 \pm 3.0$ & - & $85.4 \pm 0.2$ & $15.1 \pm 2.5$ \\
\hline & 16 & 77 & $63 \pm 0.1$ & $7.53 \pm 0.10$ & $62.3 \pm 0.3$ & - \\
\hline & 17 & 81 & $52 \pm 2.5$ & - & $82.6 \pm 0.6$ & - \\
\hline \multirow{4}{*}{ [1,2]dithiolium iodide } & 18 & 70 & $75 \pm 0.3$ & $11.03 \pm 0.03$ & $77.1 \pm 0.1$ & - \\
\hline & 19 & 95 & $73 \pm 3.2$ & $3.26 \pm 0.05$ & $90.5 \pm 0.7$ & $11.3 \pm 0.6$ \\
\hline & 20 & $\mathrm{~ns}$ & - & - & $72.0 \pm 0.1$ & - \\
\hline & 21 & 65 & - & - & $90.2 \pm 0.6$ & $17.7 \pm 3.9$ \\
\hline
\end{tabular}

a \% Inhib: percentage of enzymatic inhibition at 200,100 or $25 \mu \mathrm{M}^{\mathrm{b}}{ }^{-}-:$not determined. ${ }^{\mathrm{c}}$ ns: not studied.

d ni: not inhibition.

Different levels of TcTIM inhibition were observed with the compounds. In each compound family, one or two derivatives displayed an excellent ability to inhibit this enzyme, e.g., the [1,2]dithiole-3-thione 5, the 3-propylidene[1,2]dithioles 13 and 16, and [1,2]dithiolium salts $\mathbf{1 8}$ and 19. The best inhibitor was thione 5, which had the same potency as $\mathbf{3}$ (Figure 1) [11]. Interestingly, excluding derivative 13, no relationship between anti-epimastigote activity, of the most active compounds, and inhibition of TcTIM was observed. In the case of the 3-propylidene[1,2]dithiole 13, the $\mathrm{IC}_{50}$ against the whole parasite and TcTIM are very similar suggesting that the mechanism of action of this compound could be the inhibition of this enzyme.

However, it was not possible to establish a clear relationship between anti-epimastigote activities and the TcTIM inhibition activity for the whole series of studied compounds.

\subsubsection{Inhibition of Cruzipain}

Initially, we tested the dithioles as inhibitors of the protease cruzipain from T. cruzi at a concentration of $100 \mu \mathrm{M}$. If the compound inhibited more than $85 \%$ of enzyme activity at this dose, the IC 50 was determined (Table 2) [21]. 
In each family of compounds, two or three derivatives inhibit cruzipain in the micromolar range ([1,2]dithiole-3-thione 5, 11 and 12, 3-propylidene[1,2]dithioles $\mathbf{2}$ and 15, and [1,2]dithiolium salts 19 and 21). The best inhibitor was thione 5 which displayed low micromolar $\mathrm{IC}_{50}$ value. With the exception of compounds $\mathbf{2}$ and $\mathbf{1 5}$ which inhibit $T$. cruzi epimastigotes and cruzipain with IC50 values of the same order of magnitude (two-fold higher for cruzipain), no relationship between anti-epimastigote activity and cruzipain inhibition was observed.

Interestingly, [1,2]dithiole-3-thione 5 and 1 [1,2]dithiolium salt 19, which are inactive against the whole parasite, were able to inhibit both TcTIM and cruzipain in the low micromolar range.

\subsubsection{Inhibition of Membrane Sterol Biosynthesis}

We analyzed the capacity of the most active compounds against epimastigotes (3-propylidene[1,2] dithioles 2, and 13-15) to inhibit any of the enzymes involved in the biosynthesis of membrane sterols. To do so, we analyzed the accumulation or depletion of some intermediates or final products of this biochemical pathway. Qualitative analyses were performed by thin layer chromatography (TLC) [22]. In these experiments, derivative $\mathbf{2}$ was able to accumulate squalene and deplete ergosterol (Figure 3), as did the positive control terbinafine, a well-known antifungal with anti-T. cruzi activity. According to these results, a possible target might be the enzyme squalene-2,3-epoxidase, which catalyzes the conversion of squalene into lanosterol [23]. Compared to control, the rest of the compounds studied did not show any changes in the levels of the sterols and intermediates analyzed.

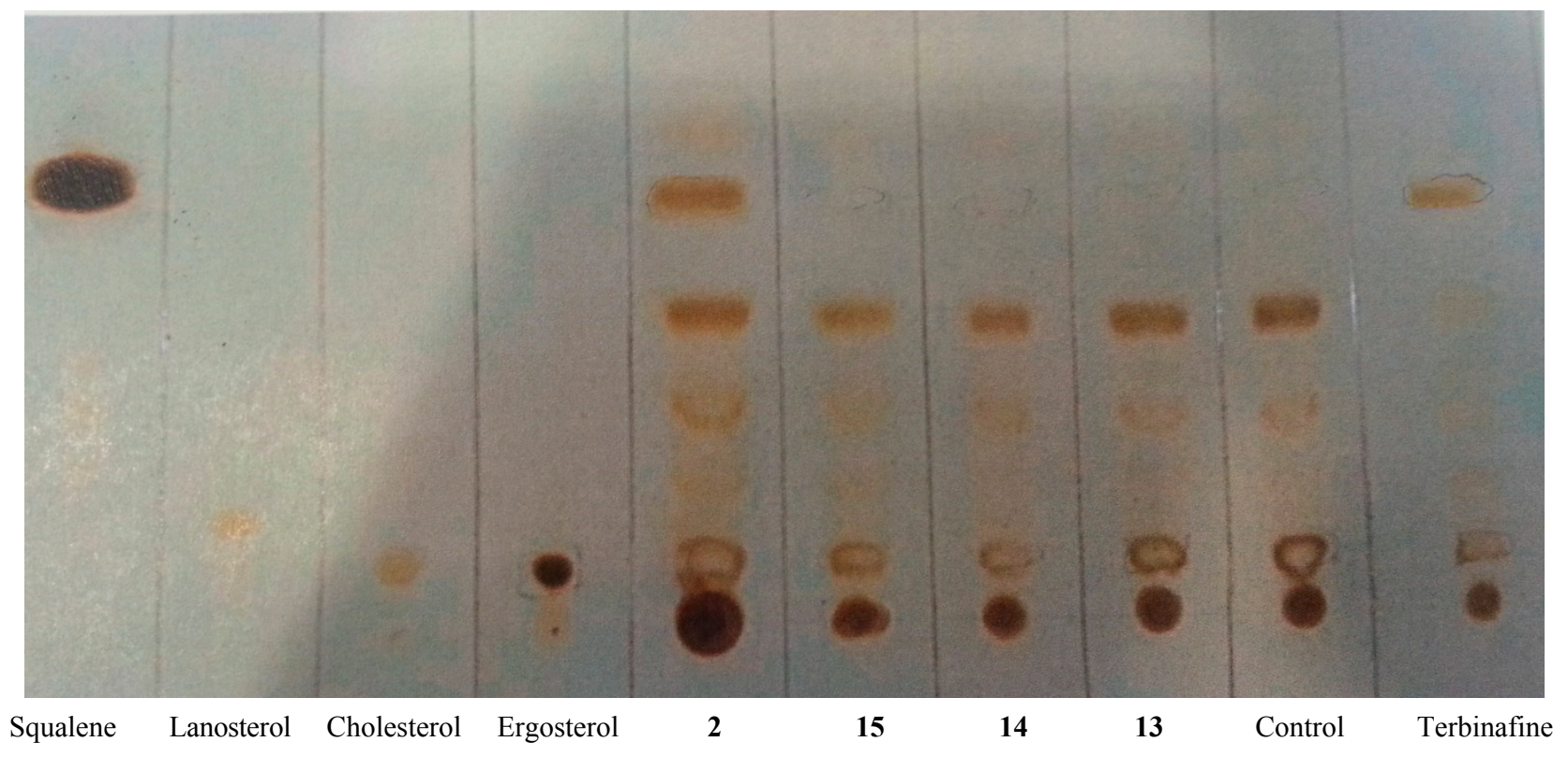

Figure 3. Example of a TLC for the study of changes in membrane sterols of T. cruzi. The lane labeled Control had untreated parasites. Terbinafine was used as a control of an accumulator of squalene for T. cruzi.

\subsection{4. ${ }^{1} \mathrm{H}-\mathrm{NMR}$ Metabolomic Studies}

To gain insight into the changes promoted by the active 3-propylidene[1,2]dithioles $\mathbf{2}$ and $\mathbf{1 4}$ in some biochemical pathways, the metabolites excreted by the parasite using ${ }^{1} \mathrm{H}-\mathrm{NMR}$ spectroscopy were 
analyzed [22]. Changes in the excreted metabolites by T. cruzi Y strain (DTU Tc II, [24]), when the parasite cells were exposed to a bioactive compound, could be indicative of the modification of the biochemical pathway(s) by the agents $[25,26]$. Spectra of the cell-free milieu of treated parasites were compared with those of the untreated $T$. cruzi-free milieu as the control. We focused mainly on the changes of excreted salts of the carboxylic acids, lactate (Lac), acetate (Ace), pyruvate (Pyr), and succinate (Succ) and the amino acids, alanine (Ala) and glycine (Gly), among the most relevant modified metabolites.

Clearly, derivative 2 significantly decreased the levels of excreted Gly and Pyr. However, derivative 14 did not modify the excreted catabolites when compared to the control (Table 3 ).

Table 3. Concentrations of metabolites excreted, carboxylic acids and amino acids, in the metabolomic studies using ${ }^{1} \mathrm{H}-\mathrm{NMR}$ (for details see Experimental Section). Each run was made in triplicate.

\begin{tabular}{ccccccc}
\hline $\begin{array}{c}\text { Compound } \\
\text { Metabolite }^{\text {b }}\end{array}$ & Gly & Succ & Pyr & Ace & Ala & Lac \\
\hline 2 & $2.11 \pm 0.11^{\mathrm{c}}$ & $5.83 \pm 0.24$ & $8.00 \pm 0.35$ & $23.28 \pm 0.86$ & $17.76 \pm 0.61$ & $8.73 \pm 0.37$ \\
14 & $2.48 \pm 0.14$ & $7.34 \pm 0.65$ & $9.47 \pm 0.53$ & $26.41 \pm 1.44$ & $20.65 \pm 1.27$ & $10.41 \pm 0.58$ \\
Control $^{\mathrm{d}}$ & $2.48 \pm 0.11$ & $6.64 \pm 0.18$ & $8.89 \pm 0.27$ & $26.06 \pm 2.07$ & $21.38 \pm 1.15$ & $9.69 \pm 0.68$ \\
\hline
\end{tabular}

${ }^{a}$ Working at the $\mathrm{IC}_{50} \times 2$ for each fraction. ${ }^{\mathrm{b}}$ The concentrations of the metabolites were calculated using DMF as the internal standard (for details see Experimental Section). ${ }^{\mathrm{c}}$ Statistically significant changes $(p<0.05$, Student's $t$-test) are shown in bold characters. ${ }^{\mathrm{d}}$ Untreated parasite.

In the metabolic pathways of $T$. cruzi the depletion of both Gly and Pyr, as occurs with the 3-propylidene[1,2]dithiole 2, probably indicates that some enzymes involved in the metabolism of L-threonine in the mitochondrion could be the potential targets of this compound [27]. The inhibition of L-threonine dehydrogenase (LTD) or acetyl-CoA:glycine $C$-acetyltransferase (ACGAT) could not only produce the reduction of excreted Gly, but also the production of acetyl-CoA (ACoA), in the mitochondrion, which are further used in the like-Krebs cycle. Consequently, if the ACoA is reduced, by inhibition of LTD or ACGAT, the parasite needs to use the Pyr entering the organelle from the cytosol and transform it to ACoA via the pyruvate dehydrogenase complex (PDC), to maintain the energetic requirements (Figure 4). This fact produces a concomitant depletion of excreted Pyr. In order to confirm this metabolic pathway, more experiments must be done, like the inhibition of LTD o ACGAT.

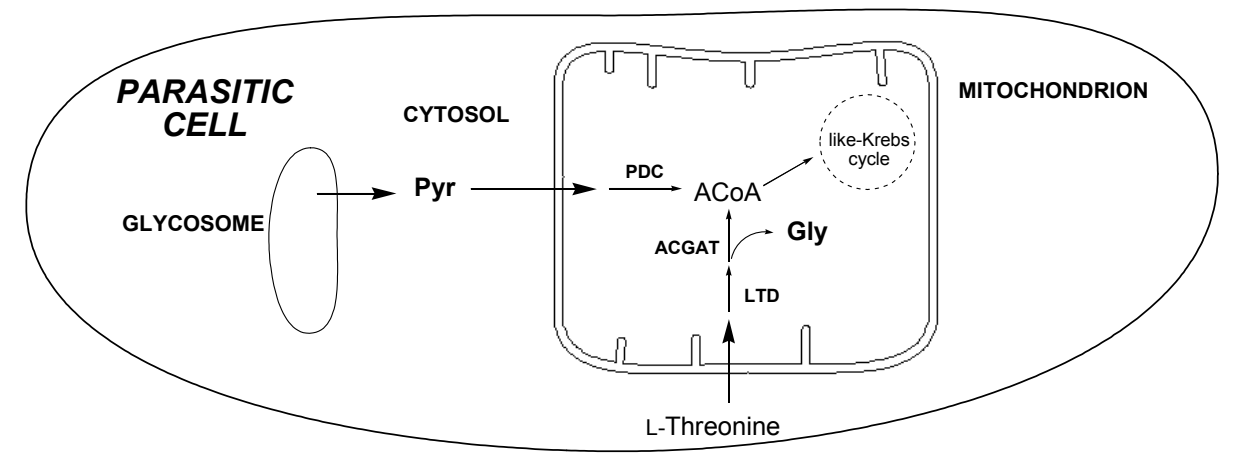

Figure 4. Possible site of action for derivative $\mathbf{2}$ in the biochemical pathways, according to the ${ }^{1} \mathrm{H}-\mathrm{NMR}$ metabolomic studies [27]. 


\section{Experimental Section}

\subsection{General}

Reagents were purchased from Aldrich and used without further purification. Melting points were performed using an Electrothermal Engineering Ltd melting point apparatus (Rochford, UK), and the results were uncorrected. ${ }^{1} \mathrm{H}-\mathrm{NMR}$ and ${ }^{13} \mathrm{C}$-NMR spectra were recorded in the indicated solvent with a Bruker DPX $400 \mathrm{MHz}$ spectrometer (Bruker, Rheinstetten, Germany). Chemical shifts are quoted in parts per million downfield from TMS and the coupling constants are in Hertz. Structural assignments were corroborated by HMBC and HSQC experiments. All solvents were dried and distilled prior to use. All the reactions were carried out in a nitrogen atmosphere. Reactions were monitored by TLC using commercially available precoated plates (Merck Kieselgel 60 F254 silica, Darmstadt, Germany) and the developed plates were examined under UV light (254 nm) or as iodine vapor stains. Column chromatography was performed using a 200 mesh silica gel. To determine the purity of the compounds, microanalyses were done on a Fisons EA 1108 CHNS-O instrument (Ipswich, UK) from vacuum-dried samples and were within \pm 0.4 of the values obtained by calculating their compositions. Compounds 1, 2, 5-11, 13, 15, 16, 19 and 20 were prepared following synthetic procedures previously reported $[14,16,17]$.

\subsection{General Synthetic Procedure for Compounds 12, 14, 17, 18, and 21}

In a 25-mL round-bottom flask, under nitrogen atmosphere, a mixture of 2-bromo-2'-acetonaphthone ( 1 equiv.), 5 or 6 ( 1 equiv.), $\mathrm{K}_{2} \mathrm{CO}_{3}$ (17 equiv.), KI (17 equiv.) and anhydrous acetone (10 $\mathrm{mL}$ per $0.2 \mathrm{mmol}$ of naphthone) was stirred at reflux for $5 \mathrm{~h}$. The solvent was then evaporated to dryness, and the resulting residue was suspended in EtOAc $(35 \mathrm{~mL})$ and washed with $35 \mathrm{~mL}$ of water. Two extractions of the water were performed with EtOAc $(2 \times 35 \mathrm{~mL})$, and the organic layers were dried over $\mathrm{Na}_{2} \mathrm{SO}_{4}$, evaporated in vacuo, and purified by column chromatography $\left(\mathrm{SiO}_{2}\right.$, hexane:AcOEt, 7:3) to give the desired products 12, 14, and 18 from compound 6 , and 17, and 21 from compound 5.

5-[4-(2-Oxo-2-naphthylethyloxy)phenyl]-3H-[1,2]dithiole-3-thione (12). Yield: 29\%; orange solid, mp: 130-133 ${ }^{\circ} \mathrm{C} ;{ }^{1} \mathrm{H}-\mathrm{NMR}\left(400 \mathrm{MHz}, \mathrm{CDCl}_{3}\right) \delta: 8.56(\mathrm{~s}, 1 \mathrm{H}), 8.06(\mathrm{dd}, J=8.6,1.7 \mathrm{~Hz}, 1 \mathrm{H}), 8.03(\mathrm{~d}, J=7.8 \mathrm{~Hz}$, $1 \mathrm{H}), 7.99(\mathrm{~d}, J=8.6 \mathrm{~Hz}, 1 \mathrm{H}), 7.94(\mathrm{~d}, J=8.2 \mathrm{~Hz}, 1 \mathrm{H}), 7.71-7.69(\mathrm{~m}, 2 \mathrm{H}), 7.64(\mathrm{~d}, J=8.8 \mathrm{~Hz}, 3 \mathrm{H}), 7.41$ (s, 1H), $7.07(\mathrm{~d}, J=8.9 \mathrm{~Hz}, 2 \mathrm{H}), 5.55(\mathrm{~s}, 2 \mathrm{H}) ;{ }^{13} \mathrm{C}-\mathrm{NMR}\left(100 \mathrm{MHz}, \mathrm{CDCl}_{3}\right) \delta: 215.3,193.3,172.7$, 161.3, 136.1, 135.0, 132.4, 131.5, 130.0, 129.9, 129.7, 129.2, 128.7, 128.0, 127.5, 127.3, 125.1, 125.0, 124.9, 123.4, 115.8, 70.6. Anal. calc. for $\mathrm{C}_{21} \mathrm{H}_{14} \mathrm{O}_{2} \mathrm{~S}_{3}$ : C 63.9\%, H 3.6\%, S 24.4\%. Found: C 64.0\%, H $3.7 \%$, S $24.3 \%$.

(E)-5-(4-Hydroxyphenyl)-3-[2-oxo-1-(2-oxo-2-naphthylethylthio)-2-naphthylethylidene]-3H-[1,2] dithiole (14). Yield: 26\%; orange oil; ${ }^{1} \mathrm{H}-\mathrm{NMR}\left(400 \mathrm{MHz}, \mathrm{CDCl}_{3}\right) \delta: 8.32(\mathrm{~s}, 1 \mathrm{H}), 8.13(\mathrm{~s}, 1 \mathrm{H}), 8.01(\mathrm{~s}, 1 \mathrm{H})$, $7.88(\mathrm{dd}, J=8.4,1.7 \mathrm{~Hz}, 1 \mathrm{H}), 7.81(\mathrm{~d}, J=8.8 \mathrm{~Hz}, 1 \mathrm{H}), 7.74(\mathrm{~d}, J=8.6 \mathrm{~Hz}, 2 \mathrm{H}), 7.69$ (d, $J=8.0 \mathrm{~Hz}, 2 \mathrm{H}), 7.66(\mathrm{~d}, J=1.8 \mathrm{~Hz}, 1 \mathrm{H}), 7.56(\mathrm{~d}, J=8.4 \mathrm{~Hz}, 2 \mathrm{H}), 7.53(\mathrm{~d}, J=1.2 \mathrm{~Hz}, 1 \mathrm{H}), 7.49-7.43$ $(\mathrm{m}, 3 \mathrm{H}), 7.33(\mathrm{~d}, J=8.7 \mathrm{~Hz}, 2 \mathrm{H}), 6.74(\mathrm{~d}, J=8.7 \mathrm{~Hz}, 2 \mathrm{H}), 5.60(\mathrm{~s}, 1 \mathrm{H}), 3.79(\mathrm{~s}, 2 \mathrm{H}) ;{ }^{13} \mathrm{C}-\mathrm{NMR}$ $\left(100 \mathrm{MHz}, \mathrm{CDCl}_{3}\right) \delta: 195.1,189.7,188.4,167.0,158.6,135-115$ (27 C), 42.2. Anal. calc. for $\mathrm{C}_{33} \mathrm{H}_{22} \mathrm{O}_{3} \mathrm{~S}_{3}$ : C 70.4\%, H 3.9\%, S 17.1\%. Found: C 70.1\%, H 3.6\%, S 17.3\%. 
5-(4-Hydroxyphenyl)-3-naphthoylmethylthio-[1,2] dithiolium iodide (18). Yield: 13\%; red oil; ${ }^{1} \mathrm{H}-\mathrm{NMR}$ $\left(400 \mathrm{MHz}_{\mathrm{CDCl}}\right) \delta: 8.51(\mathrm{~s}, 1 \mathrm{H}), 8.27(\mathrm{~d}, J=0.9 \mathrm{~Hz}, 1 \mathrm{H}), 8.11(\mathrm{~s}, 1 \mathrm{H}), 7.81(\mathrm{~s}, 1 \mathrm{H}), 7.80(\mathrm{~s}, 1 \mathrm{H})$, $7.56-7.50(\mathrm{~m}, 5 \mathrm{H}), 7.01(\mathrm{~d}, J=8.6 \mathrm{~Hz}, 2 \mathrm{H}), 5.32(\mathrm{~s}, 1 \mathrm{H}), 4.08(\mathrm{~s}, 2 \mathrm{H}) ;{ }^{13} \mathrm{C}-\mathrm{NMR}\left(100 \mathrm{MHz}, \mathrm{CDCl}_{3}\right) \delta$ : 188.1, 177.4, 168.2, 159.4, 140.0-110.0 (16 C), 33.5. Anal. calc. for $\mathrm{C}_{21} \mathrm{H}_{15} \mathrm{IO}_{2} \mathrm{~S}_{3}: \mathrm{C} 48.3 \%, \mathrm{H} \mathrm{2.9 \% ,} \mathrm{S}$ 18.4\%. Found: C $47.9 \%$, H 2.6\%, S $18.3 \%$.

(E)-5-(4-Methoxyphenyl)-3-[2-oxo-1-(2-oxo-2-naphthylethylthio)-2-naphthylethylidene]-3H-[1,2]dithiole (17). Yield: 20\%; yellow oil; ${ }^{1} \mathrm{H}-\mathrm{NMR}\left(400 \mathrm{MHz}, \mathrm{CDCl}_{3}\right) \delta: 8.34(\mathrm{~s}, 1 \mathrm{H}), 8.15(\mathrm{~s}, 1 \mathrm{H}), 8.03(\mathrm{~s}, 1 \mathrm{H})$, $7.91(\mathrm{dd}, J=8.4,1.7 \mathrm{~Hz}, 1 \mathrm{H}), 7.83(\mathrm{~d}, J=7.2 \mathrm{~Hz}, 1 \mathrm{H}), 7.76(\mathrm{dd}, J=9.0,3.1 \mathrm{~Hz}, 2 \mathrm{H}), 7.71(\mathrm{~d}, J=8.0 \mathrm{~Hz}$, 2H), $7.68(\mathrm{~d}, J=1.8 \mathrm{~Hz}, 1 \mathrm{H}), 7.58(\mathrm{~d}, J=8.4 \mathrm{~Hz}, 2 \mathrm{H}), 7.55(\mathrm{~s}, 1 \mathrm{H}), 7.52-7.45(\mathrm{~m}, 2 \mathrm{H}), 7.35$ (d, $J=8.7 \mathrm{~Hz}, 2 \mathrm{H}), 6.76(\mathrm{~d}, J=8.7 \mathrm{~Hz}, 2 \mathrm{H}), 4.00(\mathrm{~s}, 3 \mathrm{H}), 3.81(\mathrm{~s}, 2 \mathrm{H}) ;{ }^{13} \mathrm{C}-\mathrm{NMR}\left(100 \mathrm{MHz}, \mathrm{CDCl}_{3}\right) \delta$ : 195.5, 185.2, 181.4, 170.0, 161.3, 139.4-114.5 (25 C), 111.2, 106.4, 55.4, 42.3. Anal. calc. for $\mathrm{C}_{34} \mathrm{H}_{24} \mathrm{O}_{3} \mathrm{~S}_{3}$ : C 70.8\%, H 4.2\%, S 16.7\%. Found: C 70.5\%, H 3.9\%, S 16.6\%.

5-(4-Methoxyphenyl)-3-naphthoylmethylthio[1,2] dithiolium iodide (21). Yield: 17\%; red oil; ${ }^{1} \mathrm{H}-\mathrm{NMR}$ $\left(400 \mathrm{MHz}, \mathrm{CDCl}_{3}\right) \delta: 8.57(\mathrm{~s}, 1 \mathrm{H}), 8.12(\mathrm{dd}, J=8.6,1.7 \mathrm{~Hz}, 1 \mathrm{H}), 8.00(\mathrm{~d}, J=6.8 \mathrm{~Hz}, 1 \mathrm{H}), 7.95(\mathrm{~d}$, $J=8.5 \mathrm{~Hz}, 1 \mathrm{H}), 7.92(\mathrm{~s}, 1 \mathrm{H}), 7.69(\mathrm{~d}, J=8.9 \mathrm{~Hz}, 2 \mathrm{H}), 7.67(\mathrm{~s}, 1 \mathrm{H}), 7.58-7.57(\mathrm{~m}, 1 \mathrm{H}), 7.56(\mathrm{~s}, 1 \mathrm{H})$, $7.01(\mathrm{~d}, J=8.8 \mathrm{~Hz}, 2 \mathrm{H}), 4.04$ (bs, 2H), 3.91 (s, 3H); ${ }^{13} \mathrm{C}-\mathrm{NMR}\left(100 \mathrm{MHz}, \mathrm{CDCl}_{3}\right) \delta: 190.1,178.4,167.2$, 159.7, 140.0-110.0 (16 C), 54.9, 33.8. Anal. calc. for $\mathrm{C}_{22} \mathrm{H}_{17} \mathrm{IO}_{2} \mathrm{~S}_{3}: \mathrm{C} 49.2 \%$, H 3.2\%, S 17.9\%. Found: C $48.9 \%$, H $2.9 \%$, S $17.6 \%$.

\subsection{Anti-T. cruzi Test in Vitro}

We used epimastigotes of the Tulahuen 2 strain (DTU, Tc VI) growing in an axenic milieu (BHI-Tryptose). Cells from a 5-7-day-old culture were inoculated in fresh culture milieu to give an initial concentration of $1 \times 10^{6}$ cells $/ \mathrm{mL}$. The absorbance at $600 \mathrm{~nm}$ of the cells in culture was measured every day. At day 5, the milieu was inoculated with different quantities of the compounds from a stock solution in DMSO (DMSO concentration in the culture milieu never exceeded $0.4 \%$ ). The control was made in the presence of $0.4 \%$ DMSO and in the absence of compounds. Each concentration of compound was evaluated in duplicate. At day 5, the absorbance of the culture was measured and related to the control. The $\mathrm{IC}_{50}$ value was taken as the concentration of drug needed to reduce the absorbance ratio to $50 \%$.

\subsection{Unspecific in Vitro Cytotoxicity of Mammalian Cells}

J774.1 murine macrophage cells (ATCC, Manassas, VA, USA) were grown in DMEM culture milieu containing $4 \mathrm{mM} \mathrm{L-glutamine}$ and supplemented with 10\% heat-inactivated fetal calf serum. The cells were seeded in a 96-well plate $\left(5 \times 10^{4}\right.$ cells in $200 \mathrm{~mL}$ culture medium) and incubated at $37^{\circ} \mathrm{C}$ in a $5 \%$ $\mathrm{CO}_{2}$ atmosphere for $48 \mathrm{~h}$, to allow cell adhesion prior to drug testing. Afterwards, cells were exposed for $48 \mathrm{~h}$ to the compounds $(25-400 \mu \mathrm{M})$ or vehicle for control $(0.4 \% \mathrm{DMSO})$, and additional controls (cells in medium) were used in each test. Cell viability was then assessed by measuring the mitochondriadependent reduction of MTT (3-(4,5-dimethylthiazol-2-yl)-2,5-diphenyltetrazolium bromide) to formazan. For this purpose, MTT in sterile PBS (0.2\% glucose) $\mathrm{pH} 7.4$ was added to the macrophages to achieve a final concentration of $0.1 \mathrm{mg} / \mathrm{mL}$ and the cells were incubated at $37{ }^{\circ} \mathrm{C}$ for $3 \mathrm{~h}$. After 
removing the medium, formazan crystals were dissolved in $180 \mu \mathrm{L}$ of DMSO and $20 \mu \mathrm{L}$ of MTT buffer (0.1 M glycine, $0.1 \mathrm{M} \mathrm{NaCl}, 0.5 \mathrm{mM}$ EDTA, $\mathrm{pH} 10.5)$ and the absorbance at $560 \mathrm{~nm}$ was measured. The IC50 was defined as the drug concentration at which $50 \%$ of the cells were viable, relative to the control (no drug added), and was determined by analysis using OriginLab8.5 ${ }^{\circledR}$ sigmoidal regression ( $\%$ of viable cells $v s$. logarithm of the compound concentration). Samples were performed in triplicate.

\subsection{Inhibition of TcTIM}

Expression and purification of protein: TcTIM was expressed in Escherichia coli and purified as described in the literature [28]. After purification, the enzyme, dissolved in $100 \mathrm{mM}$ triethanolamine, $10 \mathrm{mM}$ EDTA and $1 \mathrm{mM}$ dithiothreitol ( $\mathrm{pH} 8$ ), was precipitated with ammonium sulfate (75\% saturation) and stored at $4{ }^{\circ} \mathrm{C}$. Before use, extensive dialysis against $100 \mathrm{mM}$ triethanolamine/10 mM EDTA (pH 7.4) was performed. Protein concentration was determined by absorbance at $280 \mathrm{~nm}\left(\varepsilon=36,440 \mathrm{M}^{-1} \cdot \mathrm{cm}^{-1}\right)$.

Enzymatic activity assays. Enzymatic activity was determined following the conversion of glyceraldehyde 3-phosphate into dihydroxyacetone phosphate [7]. The decrease in absorbance at $340 \mathrm{~nm}$ was followed in a multicell Cary spectrophotometer at $25{ }^{\circ} \mathrm{C}$. The reaction mixture $(1 \mathrm{~mL}, \mathrm{pH} 7.4)$ contained $100 \mathrm{mM}$ triethanolamine, $10 \mathrm{mM}$ EDTA, $0.2 \mathrm{mM} \mathrm{NADH}, 1 \mathrm{mM}$ glyceraldehyde 3-phosphate, and 0.9 units of $\alpha$-glycerol phosphate dehydrogenase. The reaction was initiated by addition of $5 \mathrm{ng} / \mathrm{mL}$ of the TcTIM.

For inactivation studies, Tc TIM was incubated at a concentration of $5 \mathrm{mg} / \mathrm{mL}$ in a buffer containing $100 \mathrm{mM}$ triethanolamine, $10 \mathrm{mM}$ EDTA, $\mathrm{pH} 7.4$ and $10 \%$ of DMSO at $36^{\circ} \mathrm{C}$. The mixture also contained the compounds at the indicated concentrations. Compounds were dissolved in DMSO. After $2 \mathrm{~h}, 1 \mathrm{~mL}$ was withdrawn and added to $1 \mathrm{~mL}$ of reaction mixture for the activity assay. None of the molecules tested here affected the activity of $\alpha$-glycerol phosphate dehydrogenase, the enzyme used for trapping the product.

The $\mathrm{IC}_{50}$ value was taken as the concentration of drug needed to reduce the enzymatic activity to $50 \%$. The experiments were performed in triplicate.

\subsection{Inhibition of T. cruzi Cruzipain}

Cruzipain was purified to homogeneity from epimastigotes of the Tulahuen 2 strain by ConA-Sepharose affinity chromatography, as previously described [29]. Cruzipain $\left(2.5 \mu \mathrm{M} \varepsilon=58,285 \mathrm{M}^{-1} \cdot \mathrm{cm}^{-1}\right)$ was incubated in $50 \mathrm{mM}$ acetate buffer $\mathrm{pH} 5.5$ with $50 \mathrm{mM}$ DTT and $100 \mu \mathrm{M}$ inhibitor was added, shaking the solution for $15 \mathrm{~min}$ at $27^{\circ} \mathrm{C}$. The derivatives were added diluted in DMSO, and the controls contained the same solvent concentration. The concentration of DMSO never exceeded $1 \%$ in the reaction medium. E-64 was used as a positive control of inhibition. Then, the fluorogenic substrate Z-Phe-Arg-AMC $(100 \mu \mathrm{M})$ was added and the fluorescence was measured during $10 \mathrm{~min}$ at intervals of $3 \mathrm{~s}$ (excitation at $350 \mathrm{~nm}$ and emission at $460 \mathrm{~nm}$ ) using a Varioskan Flash Spectrophotometer. From the slope of the negative control, we calculated the total (100\%) enzyme activity, while the slopes obtained in the presence of the compounds yielded the percentage of remaining enzyme activity. The percentage of enzyme inhibition was determined as $100 \%$ of remaining enzyme activity. The experiments were done in duplicate. 


\subsection{Inhibition of Membrane Sterol Biosynthesis}

The parasites, epimastigotes of Y strain of T. cruzi (DTU Tc II), were grown in $6 \mathrm{~mL}$ of BHT milieu in culture bottles. Compounds at their respective $\mathrm{IC}_{50}$ were incubated for $72 \mathrm{~h}$ at $28^{\circ} \mathrm{C}$ with the parasite, starting from a parasitic load of 10 million per $\mathrm{mL}$. A negative control was performed with parasites in the absence of compounds. The parasites in the positive control were incubated with terbinafine $\left(\mathrm{IC}_{50}=44.7 \mu \mathrm{M}\right)$, which has proven inhibitory activity on membrane sterol biosynthesis. The extraction of membrane sterols was performed on completion of the incubation. For this purpose, the content of the culture bottle was centrifuged at $3000 \mathrm{rpm}$ for $10 \mathrm{~min}$, the supernatant was discarded and the pellet was suspended in sodium phosphate buffer solution $(6 \mathrm{~mL}, 0.05 \mathrm{M}, \mathrm{pH} 7.4)$. Then it was centrifuged again at $3000 \mathrm{rpm}$ for $10 \mathrm{~min}$ and the supernatant was discarded. The resulting pellet was resuspended in a chloroform/methanol $(2: 1)$ mixture $(5 \mathrm{~mL})$ and the suspension was kept at $4{ }^{\circ} \mathrm{C}$ for $12 \mathrm{~h}$. Then, a saturated $\mathrm{NaCl}$ solution $(5 \mathrm{~mL})$ was added and the mixture extracted once with chloroform $(3 \mathrm{~mL})$ and once with hexane $(3 \mathrm{~mL})$ with care to avoid taking any aqueous phase. The extracted volume was applied to a silica gel TLC plate. Chromatography was performed eluting with hexane, two runs to identify squalene, and once with hexane/EtOAc (8:2) for ergosterol. The spots on the plate were revealed under ultraviolet light or by exposure to iodine vapors. Also, controls and commercial samples of ergosterol, lanosterol, cholesterol and squalene were run on the TLC plate [30]. The experiment was done in triplicate.

\section{8. ${ }^{1} H$-NMR Study of the Excreted Metabolites}

For the ${ }^{1} \mathrm{H}-\mathrm{NMR}$ spectroscopic studies, T. cruzi cells (Y strain, DTU Tc II) treated for 2 days, with each studied compound at concentrations corresponding to $2 \times \mathrm{IC}_{50}$ values $(5 \mathrm{~mL})$ were centrifuged at $1500 \times \mathrm{g}$ for $10 \mathrm{~min}$ at $4{ }^{\circ} \mathrm{C}$. The pellet was discarded, and the parasite-free supernatant was stored at $-20^{\circ} \mathrm{C}$ until use. Before measuring, DMF $(0.1 \mathrm{~mL}, 10 \mathrm{mM})$ as the internal standard and $\mathrm{D}_{2} \mathrm{O}(0.1 \mathrm{~mL})$ were added to the supernatant $(0.3 \mathrm{~mL})$. ${ }^{1} \mathrm{H}-\mathrm{NMR}$ experiments were recorded at $20{ }^{\circ} \mathrm{C}$ on a Bruker Advance DPX-400 spectrometer (Bruker), operating at $400.132 \mathrm{MHz}$, with a $5 \mathrm{~mm}$ broadband inverse geometry probe. The acquisition parameters included: $90^{\circ}$ pulse (zgpr, advance-version v 1.7.10.2, 1D sequence with $\mathrm{fl}$ presaturation), 128 scans, and spectral width of $14.983 \mathrm{ppm}$. The acquisition time was 1.3664 s. Signal intensities were calculated by performing appropriate baseline corrections and then integrating the area under each of the resonances using MestRe-C NMR software. Spectra were analyzed using the Topspin 1.3 software package. The spectra were registered with water suppression in $5 \mathrm{~mm}$ NMR (Aldrich, St. Louis, MO, USA) sample tubes. The chemical displacements used to identify the respective metabolites were previously confirmed by adding each analyzed metabolite to the studied supernatant, as well as by the study of a control solution with $4 \mu \mathrm{g} / \mathrm{mL}$ of each metabolite in buffer (phosphate, $\mathrm{pH}=7.4$ ). Each run was done at least in triplicate and the Student $\mathrm{t}$ test was used to analyze the significance of the changes. The chemical shifts $(\delta, \mathrm{ppm})$ and multiplicity of the analyzed catabolites were: Ala (alanine), 1.316, d; Lac (lactate), 1.466, d; Ace (acetate), 1.904, s; Pyr (pyruvate), 2.357, s; Succ (succinate), 2.392, s; Gly (glycine), 3.547, s [31]. 


\section{Conclusions}

We have identified four derivatives, $2,13,14$, and 15, with good anti-T. cruzi activity and selectivity profiles with different kinds of effects on the biochemical pathways of the parasite (Figure 5).<smiles>CC(=O)COc1ccc(C2=CC(=C(SCC(C)=O)C(C)=O)SS2)cc1</smiles><smiles>O=C(CS/C(C(=O)c1ccccc1)=C1/C=C(c2ccc(O)cc2)SS1)c1ccccc1</smiles><smiles>O=C(CSC(C(=O)c1ccc2ccccc2c1)=C1C=C(c2ccc(O)cc2)SS1)c1ccc2ccccc2c1</smiles><smiles>COc1ccc(C2=CC(=C(SCC(C)=O)C(C)=O)SS2)cc1</smiles>

$$
\begin{gathered}
\mathrm{IC}_{50, \mathrm{epi}}=7.7 \mu \mathrm{M} \\
\mathrm{SI}=3.1
\end{gathered}
$$

$$
\begin{aligned}
& I_{50, \text { epi }}=5.5 \mu \mathrm{M} \\
& \text { SI }=6.2
\end{aligned}
$$

$\mathrm{IC}_{50, \mathrm{epi}}=4.9 \mu \mathrm{M}$

$\mathrm{SI}=12.8$
- $\mathrm{IC}_{50, \text { cruzipain }}=15.5 \mu \mathrm{M}$ - squalene accumulation in the parasite - depletion of Gly and Pyr elimination
$-\mathrm{IC}_{50, \text { TcTIM }}=3.35 \mu \mathrm{M}$

Figure 5. Summary of the identified 3-(alkylthio)propylidene-3H-[1,2]dithiole derivatives as the best anti-T. cruzi agents.

Specifically, 3-(alkylthio)propylidene-3H-[1,2]dithiole $\mathbf{2}$ could be considered as a multitarget anti-T. cruzi agent showing modest Tc TIM and cruzipain inhibitions, at the micromolar level, and effects on the membrane sterol biosynthesis and on some mitochondrial enzymes. The dithiole $\mathbf{2}$ could be classified as a symbiotic agent [32].

On the other hand, we identified new hits, for further structural modifications, $3 H$-[1,2]dithiole-3thiones, 3-(alkylthio) propylidene-3H-[1,2]dithioles, and [1,2]dithiolium iodide, as pharmacophores for TcTIM and cruzipain inhibitors.

Further studies are needed in order to optimize the chemical structure and propose these systems as scaffolds for drugs against Chagas disease. 


\section{Acknowledgments}

The authors would like to thank the Comisión Sectorial de Investigación Científica (CSIC)-UdelaR (grants CSIC-N ${ }^{\circ} 210$, CSIC-N ${ }^{\circ} 155$, and CSIC-PAIE $N^{\circ} 112$ ) of Uruguay and CONACYT (grant $\mathrm{N}^{\circ}$ 167823) of México. Collaborative work was performed under the auspices of the Iberoamerican Program for Science and Technology (CYTED), network RIDIMEDCHAG. JV, and MaCo thank ANII (Uruguay) for their scholarships.

\section{Author Contributions}

M.T.G.-P., A.G.-P., R.P.-M., H.C. and M.G. designed research and experiments; Ma.Co. C.S., B.D., V.M., J.V., G.A., M.C., L.C., B.A.-L., and N.C. performed research; M.G. and H.C. analyzed the data; R.P.-M., M.G. and H.C. wrote the paper. All authors read and approved the final manuscript.

\section{Conflicts of Interest}

The authors declare no conflict of interest.

\section{References}

1. World Health Organization (WHO). World Health Organization: Global Health Observatory Data Repository; WHO: Geneva, Switzerland, 2011; Volume 2011.

2. Barrett, M.P.; Croft, S.L. Management of trypanosomiasis and leishmaniasis. Br. Med. Bull. 2012, 104, 175-196.

3. Tekiel, V.; Alba-Soto, C.D.; González Cappa, S.M.; Postan, M.; Sánchez, D.O. Identification of vaccines candidates against Trypanosoma cruzi by immunization with sequential fractions of an epimastigote-subtracted trypomastigote cDNA expression library. Vaccine 2009, 27, 1323-1332.

4. Wilkinson, S.R.; Kelly, J.M. Trypanocidal drugs: Mechanisms, resistance and new targets. Expert Rev. Mol. Med. 2009, 11, e31, doi:10.1017/S1462399409001252.

5. Castro, J.A.; de Mecca, M.M.; Bartel, L.C. Toxic side effects of drugs used to treat Chagas' disease (American trypanosomiasis). Hum. Exp. Toxicol. 2006, 25, 471-479.

6. Cerecetto, H.; González, M. Anti-T. cruzi agents: Our experience in the evaluation of more than five hundred compounds. Mini Rev. Med. Chem. 2008, 8, 1355-1383.

7. Gomez-Puyou, A.; Saavedra-Lira, E.; Zubillaga, Becker, I.; R.A.; Rojo-Dominguez, A.; Perez-Montfort, R.; Using evolutionary changes to achieve species-specific inhibition of enzyme action—studies with triosephosphate isomerase. Chem. Biol. 1995, 2, 847-855.

8. Velanker, S.S.; Ray, S.S.; Gokhale, R.S.; Suma, S.; Balaram, H.; Balaram, P.; Murthy, M.R.N. Triosephosphate isomerase from Plasmodium falciparum: The crystal structure provides insights into antimalarial drug design. Structure 1997, 5, 751-761.

9. Cortés-Figueroa, A.A.; Pérez-Torres, A.; Salaiza, N.; Cabrera, N.; Escalona-Montaño, A.; Rondán, A.; Aguirre-García, M.; Gómez-Puyou, A.; Pérez-Montfort, R.; Becker, I. A monoclonal antibody that inhibits Trypanosoma cruzi growth in vitro and its reaction with intracellular triosephosphate isomerase. Parasitol. Res. 2008, 102, 635-643. 
10. Alvarez, G.; Aguirre-López, B.; Varela, J.; Cabrera, M.; Merlino, A.; López, G.V.; Lavaggi, M.L.; Porcal, W.; di Maio, R.; González, M.; et al. Massive screening yields novel and selective Trypanosoma cruzi triosephosphate isomerase dimer-interface-irreversible inhibitors with anti-trypanosomal activity. Eur. J. Med. Chem. 2010, 45, 5767-5772.

11. Alvarez, G.; Aguirre-López, B.; Cabrera, N.; Marins, E.B.; Tinoco, L.; Batthyány, C.I.; Tuena de Gómez-Puyou, M.; Puyou, A.G.; Pérez-Montfort, R.; et al. 1,2,4-Thiadiazol-5(4H)-ones: A new class of selective inhibitors of Trypanosoma cruzi triosephosphate isomerase. Study of the mechanism of inhibition. J. Enzyme Inhib. Med. Chem. 2013, 28, 981-989.

12. Alvarez, G.; Martínez, J.; Aguirre-López, B.; Cabrera, N.; Pérez-Díaz, L.; Tuena de Gómez-Puyou, M.; Gómez-Puyou, A.; Pérez-Montfort, R.; Garat, B.; et al. New chemotypes as Trypanosoma cruzi triosephosphate isomerase inhibitors: A deeper insight into the mechanism of inhibition. J. Enzyme Inhib. Med. Chem. 2014, 29, 198-204.

13. Minini, L.; Álvarez, G.; González, M.; Cerecetto, H.; Merlino, A. Molecular docking and molecular dynamics simulation studies of Trypanosoma cruzi triosephosphate isomerase inhibitors. Insights into the inhibition mechanism and selectivity. J. Mol. Graph. Model. 2015, 58, 40-49.

14. Couto, M.; de Ovalle, S.; Cabrera, M.; Cerecetto, H.; González, M. Searching phase II enzymes inducers, from Michael acceptor-[1,2]dithiolethione hybrids, as cancer chemopreventive agents. Future Med. Chem. 2015, in press, doi:10.4155/FMC.15.32.

15. El-Bassiouni, E.A.; Helmy, M.H.; Abdel-Hamid, M.A.; Shohayeb, M.A.; Ismail, S.S. In vitro effect of low concentrations of oltipraz on the antioxidant defence of mouse hepatocytes and Schistosoma mansoni worms. Br. J. Biomed. Sci. 2004, 61, 15-21.

16. Bottcher, B.; Bauer, F. Trithiones, V. Some new trithiones. Chem. Ber. 1951, 84, 458-463.

17. Couto, M.; Cabrera, M.; Echeverría, G.A.; Piro, O.E.; González, M.; Cerecetto, H. A serendipitous one-step conversion of $3 H$-1,2-dithiole-3-thione to $(E)$-3-[1-(alkylthio)alkylidene]-3H-1,2-dithiole: An experimental and theoretical study. Mol. Divers. 2014, 18, 285-294.

18. Cosentino, R.O.; Agüero, F. A simple strain typing assay for Trypanosoma cruzi: Discrimination of major evolutionary lineages from a single amplification product. PLoS Negl. Trop. Dis. 2012, 6, e1777.

19. Álvarez, G.; Varela, J.; Cruces, E.; Fernández, M.; Gabay, M.; Leal, S.M.; Escobar, P.; Sanabria, L.; Serna, E.; Torres, S.; et al. Identification of a new amide-containing thiazole as a drug candidate for treatment of Chagas' disease. Antimicrob. Agents Chemother. 2015, 59, 1398-1404.

20. Molinspiration Online Property Calculation Toolkit. Available online: http://www.molinspiration.com/ cgi-bin/properties (accessed on 13 May 2015).

21. Ríos, N.; Varela, J.; Birriel, E.; González, M.; Cerecetto, H.; Merlino, A.; Porcal, W. Identification of novel benzimidazole derivatives as anti-Trypanosoma cruzi agents: Solid-phase synthesis, structure-activity relationships and molecular docking studies. Future Med. Chem. 2013, 5, 1719-1732.

22. Varela, J.; Serna, E.; Torres, S.; Yaluff, G.; Vera de Bilbao, N.I.; Miño, P.; Chiriboga, X.; Cerecetto, H.; González, M. In vivo anti-Trypanosoma cruzi activity of hydro-ethanolic extract and isolated active principles from Aristeguietia glutinosa and mechanism of action studies. Molecules 2014, $19,8488-8502$.

23. Urbina, J.A. Ergosterol biosynthesis and drug development for Chagas disease. Mem. Inst. Oswaldo Cruz 2009, 104, 311-318. 
24. Mendes, T.A.; Reis Cunha, J.L.; de Almeida, L.R.; Rodrigues, L.G.F.; Lemos, L.D.; dos Santos, A.R.; da Câmara, A.C.; Galvão, L.M.; Bern, C.; Gilman, R.H.; et al. Identification of strain-specific B-cell epitopes in Trypanosoma cruzi using genome-scale epitope prediction and high-throughput immunoscreening with peptide arrays. PLoS Negl. Trop. Dis. 2013, 7, e2524.

25. Benitez, D.; Cabrera, M.; Hernández, P.; Boiani, L.; Lavaggi, M.L.; di Maio, R.; Yaluff, G.; Serna, E.; Torres, S.; Ferreira, M.E.; et al. 3-Trifluoromethylquinoxaline $N, N^{\prime}$-dioxides as anti-trypanosomatid agents. Identification of optimal anti-T. cruzi agents and mechanism of action studies. J. Med. Chem. 2011, 54, 3624-3636.

26. Boiani, L.; Aguirre, G.; González, M.; Cerecetto, H.; Chidichimo, A.; Cazzulo, J.J.; Bertinaria, M.; Guglielmo, S. Furoxan-, alkylnitrate-derivatives and related compounds as anti-trypanosomatid agents: Mechanism of action studies. Bioorg. Med. Chem. 2008, 16, 7900-7907.

27. Bringaud, F.; Riviere, L.; Coustou, V. Energy metabolism of trypanosomatids: Adaptation to available carbon sources. Mol. Biochem. Parasitol. 2006, 149, 1-9.

28. Ostoa-Saloma, P.; Garza-Ramos, G.; Ramírez, J.; Becker, I.; Berzunza, M.; Gómez-Puyou, A.; Landa, A.; Tuena de Gómez-Puyou, M.; Pérez-Montfort, R. Cloning, expression, purification and characterization of triosephosphate isomerase from Trypanosoma cruzi. Eur. J. Biochem. 1997, 244, 700-705.

29. Labriola, C.; Cazzulo, J.J. Purification and partial characterization of a cysteine proteinase from Trypanosoma rangeli. FEMS Microbiol. Lett. 1995, 129, 143-148.

30. Gerpe, A.; Alvarez, G.; Benítez, D.; Boiani, L.; Quiroga, M.; Hernández, P.; Sortino, M.; Zacchino, S.; González, M.; Cerecetto, H. 5-Nitrofuranes and 5-nitrothiophenes with anti-Trypanosoma cruzi activity and ability to accumulate squalene. Bioorg. Med. Chem. 2009, 17, 7500-7509.

31. Benítez, D.; Casanova, G.; Cabrera, G.; Galanti, N.; Cerecetto, H.; González, M. Initial studies on mechanism of action and cell death of active $N$-oxide-containing heterocycles in Trypanosoma cruzi epimastigotes in vitro. Parasitology 2014, 141, 682-696.

32. Barreiro, E.J.; Manssour Fraga, C.A. New insights for multifactorial disease therapy: The challenge of the symbiotic drugs. Curr. Drug Ther. 2008, 3, 1-13.

Sample Availability: Samples of the studied compounds are available from the authors.

(C) 2015 by the authors; licensee MDPI, Basel, Switzerland. This article is an open access article distributed under the terms and conditions of the Creative Commons Attribution license (http://creativecommons.org/licenses/by/4.0/). 